\author{
Magdalena Ulanowska, Beata Olas \\ Katedra Biochemii Ogólnej \\ Instytut Biochemii \\ Wydział Biologii i Ochrony Środowiska \\ Uniwersytet Łódzki \\ Pomorska 141/143, 90-236 Eódź \\ E-mail: magdalena.ulanowska@edu.uni.lodz.pl
}

\title{
FITOZWIĄZKI - WAŻNE SKŁADNIKI SUPLEMENTÓW DIETY ORAZ ICH WPŁYW NA ZDROWIE CZŁOWIEKA
}

\section{WSTEP}

Fitozwiąki to bioaktywne syntetyzowane przez rośliny substancje chemiczne, chroniace rośliny przed szkodliwym działaniem środowiska zewnętrznego, wywoływanym m.in. przez drobnoustroje, promieniowanie UV, toksyczne zwiazki i inne niekorzystne warunki panujace $w$ miejscu ich występowania, takie jak stres czy susza. Ponadto, determinuja one barwę, aromat i smak roślin oraz wpływaja na regulacje ich wzrostu. Fitozwiązki charakteryzuja się właściwościami bakteriobójczymi, grzybobójczymi, owadobójczymi i antyoksydacyjnymi, które sa ściśle zwiazane $z$ ich budowa chemiczna, odpowiadajaca $\mathrm{m} . \mathrm{in}$. za neutralizację wolnych rodników. Z tego względu moga one bezpośrednio oddziaływać na organizm człowieka poprzez działanie protekcyjne i lecznicze wobec wielu chorób, związanych m.in. ze stresem oksydacyjnym (KocHE i współaut. 2016). Fitozwiąki dzięki właściwościom leczniczym i odżywczym moga stanowić istotne komponenty suplementów diety (Koss-MiKOŁAJCZYK i BARTOSzEK 2019). Suplement diety, według ustawy „Bezpieczeństwo żywności i żywienia", to środek spożywczy, który stosuje się nie w celu leczniczym, lecz jedynie, aby uzupełnić dietę w różne składniki odżywcze lub fizjologiczne. Mimo to, suplementy moga istotnie oddziaływać na organizm, efektywnie wspomagajac farmakoterapię, przy jednoczesnym niewielkim ryzyku pojawienia się niepożądanych skutków (OsTROWSKA i KRZEWIŃSKI 2017). Celem pracy jest przedstawienie najnowszej wiedzy na temat roli fitozwią- ków zawartych w roślinach w produkcji suplementów diety oraz ich wpływ na zdrowie człowieka.

\section{FITOZWIAZKI CEBULI, CZOSNKU, IMBIRU I POMIDORA W \\ SUPLEMENTACH DIETY - OGÓLNA CHARAKTERYSTYKA}

Skład suplementów diety charakteryzuje się dużym zróżnicowaniem, jednak główny komponent tych preparatów stanowia rośliny lub ich wyciagi, dodawane w dopuszczalnej dawce substancji bioaktywnych (SCHLEGEL-ZAWADZKA i BARTECZKO 2009). Dużym zainteresowaniem jako składniki suplementów cieszą się przyprawy, które oprócz pełnienia funkcji konserwantów i ulepszaczy smaku, wykazuja działanie prozdrowotne. Powszechnie stosowane sa rośliny takie jak: cebula zwyczajna (Allium cepa), czosnek pospolity (Allium sativum) i imbir lekarski (Zingiber officinale), posiadające liczne właściwości terapeutyczne, ściśle związane $z$ tym, iż stanowią bogate źródło fitozwiązków. Sugeruje się, że w suplementach diety często znajduja się czynne farmakologicznie składniki, które moga przyczyniać się do regulacji homeostazy przez oddziaływanie na aktywność płytek krwi (inhibicje agregacji płytek krwi) oraz redukcje kwasu arachidonowego na skutek różnych mechanizmów, np. interakcji farmakodynamicznych. Duże znaczenie w tym kontekście maja wymienione już rośliny oraz pomidor (Solanum lycopersicum L.). Jest to ściśle zwiazane $z$ ich składem chemicznym, m.in. zawartościa związków fenolowych czy 
organosiarkowych (izotiocyjanin) w przypadku czosnku. Przedmiotem badań jest także wpływ suplementów diety na proces krzepnięcia krwi - ich samodzielne działanie lub $\mathrm{w}$ połączeniu $\mathrm{z}$ lekami przeciwpłytkowymi, np. aspiryna (OlAS 2018, 2019). Zwiazki fenolowe obecne $\mathrm{w}$ cebuli sa powszechnie znane jako silne antyoksydanty, które również znalazły zastosowanie $\mathrm{w}$ produkcji suplementów diety. Kwercetyna, jako zwiazek uzupełniajacy dietę, stanowi składnik licznych suplementów diety, wykorzystywanych w leczeniu cukrzycy i zaburzeń wchłaniania. Ponadto, wchodzi w skład środków antyalergicznych (Zdrovit, Alercal), preparatów poprawiajacych kondycję skóry, włosów i paznokci (Artilane) oraz produktów wpływajacych na narzad wzorku (Amerisus) (KoBYLIŃSKA i JANAS 2015). Dzięki zdolności do wzmacniania działania kwasu askorbinowego, kwercetyna znalazła także zastosowanie do produkcji wielu leków (KA£WA 2019).

Czosnek pospolity zawiera wiele ważnych substancji bioaktywnych. Bezwonne ekstrakty czosnku obecne $\mathrm{w}$ suplementach diety to dobra alternatywa dla osób, które odczuwaja dyskomfort zwiazany $z$ charakterystycznym zapachem i smakiem czosnku. Suplementy bazujace na czosnku suszonym i sproszkowanym stanowily przedmiot badań już od połowy lat 80. ubiegłego wieku i skupiały się głównie na wpływie tego surowca na poziom cholesterolu $\mathrm{w}$ surowicy oraz na ciśnienie krwi. Większość przeprowadzonych badań klinicznych nad potencjalnym leczniczym działaniem czosnku na układ sercowo-naczyniowy bazowało na przyjmowaniu suplementów standaryzowanych pod względem potencjału alliny lub allicyny (patrz: Fitozwiazki czosnku - allina, allicyna i ajoen).

(LAWSON i HUNSAKER 2018). Najczęściej czosnek przyjmowany jest $\mathrm{w}$ postaci surowej, jednak znane sa także komercyjne preparaty produkowane na jego podstawie. Taki środek powinien zawierać dzienna dawkę allicyny w ilości 6-10 mg (LIs i współaut. 2013). U osób dorosłych cierpiących na choroby układu krażenia czosnek jest stosowany w dawce: jeden średniej wielkości ząbek czosn$\mathrm{ku}$ dziennie od 0,5 do $1 \mathrm{~g}$ suchego proszku $\mathrm{z}$ czosnku na dobę, ewentualnie $\mathrm{w}$ formie środków zawierających od 6 do $10 \mathrm{mg}$ alliny $\mathrm{w}$ jednej dawce dziennie (NowaK 2009). Przy suplementacji czosnkiem należy pamiętać, że surowiec ten stosowany wraz ze środkami przeciwgoraczkowymi (np. paracetamolem) może powodować wzrost ryzyka wystapienia dysfunkcji wattroby, a podczas jednoczesnego przyjmowania czosnku i preparatów antykoagulacyjnych występuje ryzyko krwawień. Na czosnek powinny uważać także kobiety karmiące, ponieważ związki siarki moga przedo- stawać się do mleka (Lis i współaut. 2013, PROKOP i ASTEL 2017). Ostatnio popularność zyskał także czosnek niedźwiedzi, stosowany jako przyprawa konserwująca żywność i dodatek do potraw oraz w postaci oleju czosnkowego. Na rynku pojawily się także parafarmaceutyki i suplementy diety produkowane na jego bazie (DżUgAN i współaut. 2014).

$Z$ podziemnych kłaczy imbiru wytwarza się proszki, syropy i oleje, stosowane sa także w produkcji suplementów diety, jako dodatek do produktów spożywczych i napojów. Badania kliniczne sugeruja, że pożądane skutki farmakologiczne uzyskuje się przy dawce od $250 \mathrm{mg}$ do $1 \mathrm{~g}$ korzenia w formie sproszkowanej, pod postacia kapsułek podawanych do czterech razy na dobę (KIELISzEK i współaut. 2020). Ze względu na przeciwwymiotne działanie imbiru, jest on zalecany np. w przypadku wystapienia choroby lokomocyjnej, niestrawności czy braku łaknienia, a także dla kobiet spodziewających się dziecka, dla których zalecane jest przyjmowanie od 2 do $4 \mathrm{~g}$ imbiru w 2-3 porcjach dziennie, aby złagodzić nudności ciążowe. $\mathrm{Na}$ rynku istnieje wiele preparatów zawierajacych ten niezwykle cenny surowiec, m.in. kapsułki wypełnione kłączem w postaci sproszkowanej, ekstrakty suche i płynne czy pastylki do żucia. Imbir można spożywać jako surowiec świeży: wyciskać, gotować lub przygotowywać w postaci herbaty imbirowej z korzenia (ŁAŻEWSKA i współaut. 2019, ABDULWASE i współaut. 2020).

$\mathrm{W}$ przypadku pomidora, to wyizolowany likopen (związek organiczny należacy do karotenoidów o właściwościach antyoksydacyjnych) stanowi składnik suplementów diety i podawany jest np. w formie kapsułek. Likopen jest powszechnym komponentem suplementów diety - warto wybierać jednak produkty jednocześnie wzbogacone o oleje roślinne, ponieważ tłuszcze zwiększaja dyspersję likopenu, a tym samym biodostępność jego stężenie we krwi będzie wówczas wyższe (BELTER i współaut. 2011). Ostatnio naukowcy uznali rozpuszczalny $\mathrm{w}$ wodzie ekstrakt $z$ pomidora, o nazwie handlowej Fruitflow, za pierwszy komercyjny produkt w Europie, w którego skład wchodza biodostępne zwiazki o aktywności kardioprotekcyjnej i przeciwzapalnej. Jego właściwości najprawdopodobniej skorelowane sa $z$ obecnościa likopenu o działaniu antyoksydacyjnym [hamowanie utleniania cholesterolu oraz frakcji lipoprotein o niskiej gęstości (LDL)] oraz przeciwzapalnym, istotnych $\mathrm{w}$ zapobieganiu miażdżycy (OlAS 2018). Stosowanie likopenu ma wiele zalet - brak skutków ubocznych przy odpowiednich dawkach, szeroka dostępność i niskie koszty (Mozos i współaut. 2018). 


\section{FITOZWIĄZKI ZAWARTE W CEBULI}

\section{CYJANIDYNA I GLIKOZYD-3-O CYJANIDYNY}

Cyjanidyna to purpurowo-różowy (w pH obojętnym) związek należący do antocyjanidyn (antocyjany) o budowie C6-C3-C6, który występuje m.in. w cebuli czerwonej, nadając jej kolor (METRANI i współaut. 2020). Antocyjanidyny to zwiazki chemiczne zwane też aglikonami, zaś ich glikozydy nazywane sa antocyjanami (RYK 2018). Antocyjany stosowane sa jako barwniki spożywcze, a ze względu na swoje cenne właściwości prozdrowotne, m.in. antyoksydacyjne, stanowia istotny komponent żywności (SALUK-JUSZCZAK 2010). Średnia zawartość cyjanidyny w cebuli czerwonej wynosi około $13 \mathrm{mg}$ na 100 g produktu (GHERIBI 2011). Związek ten wykazuje aktywność przeciwglikacyjna. Glikacja to nieenzymatyczna N-glikozylacja białek, w wyniku której powstaje wiązanie pomiędzy grupa karbonylowa cukrowca lub jego pochodnych a pierwszorzędowa grupa aminowa białka. Reakcja ta jest wzmożona szczególnie w hiperglikemii zwiazanej $z$ cukrzyca, a nagromadzenie końcowych produktów procesu może prowadzić do dysfunkcji białek ustrojowych (KLEPACKA 2013). Cyjanidy- na wykazuje zdolność do inhibicji jelitowej a-glukozydazy i trzustkowej a-amylazy - enzymów regulujacych trawienie węglowodanów, a także zdolnych do stymulacji wydzielania insuliny (SUANTAWEE i współaut. 2020). Wyniki badań SuANTAWEe i wspólaut. (2020) przeprowadzone na szczurach sugeruja, że cyjanidyna to środek zapobiegajacy uszkodzeniom oksydacyjnym i apoptozie w komórkach $\beta$-trzustki, wywołanym przez metyloglioksal - zwiazek stymulujacy glikację białek. Zatem cyjanidyna może stanowić istotny składnik żywności funkcjonalnej oraz nutraceutyków o aktywności przeciwcukrzycowej(SuANTAWEe i współaut. 2020). Nutraceutyki sa definiowane jako substancje o aktywności biologicznej, znajdujace się w środkach spożywczych lub żywności, majace pozytywny wpływ na zdrowie, np. działajacc prewencyjnie lub leczniczo wobec różnych chorób, np. sercowo-naczyniowych (OLEDZKA 2007, OLAS 2018). Glikozyd-3-O-cyjanidyny (Cy-3-G, C3G) jest wytwarzany w szlaku flawan-3-olu (Olivas-Aguirre i współaut. 2016). Olivas-AGUIRRE i współaut. (2016) opracowali tabelę, podsumowujacca dotychczasową wiedzę o mechanizmach działania glikozydu-3-O-cyjanidyny na komórki i różne linie komórkowe (Tabela 1).

Tabela 1. Działanie glikozydu-3-O-cyjanidyny na poszczególne linie komórkowe lub komórki (OLIVAS-AGUIRRE i współaut. 2016). Zmodyfikowano.

\begin{tabular}{|c|c|c|}
\hline Linia komórkowa/komórki & Dawka glikozydu-3-O-cyjanidyny & Mechanizm działania \\
\hline Erytrocyty & $10-100 \mu \mathrm{M}$ & $\begin{array}{l}\text { Spadek cholesterolu i TBARS w błonach } \\
\text { komórkowych }\end{array}$ \\
\hline $\begin{array}{l}\text { Ludzkie adherentne makrofagi ( } \\
\text { komórek U937), komórki nabłon- } \\
\text { kowe jamy ustnej (GMSM-K) i fi- } \\
\text { broblasty dziąsła (HGF-1) }\end{array}$ & $5-25 \mu \mathrm{g} / \mathrm{mL}$ & $\begin{array}{l}\text { Spadek poziomu IL-6 w makrofagach, cy- } \\
\text { toprotekcja linii komórkowych GMSM-K, } \\
\text { HGF-1 wobec toksyczności nikotyny }\end{array}$ \\
\hline $\begin{array}{l}\text { Ludzka linia komórkowa raka żo- } \\
\text { łądka (KATO III) }\end{array}$ & $12,5 \mu \mathrm{M}$ & $\begin{array}{l}\text { Spadek VacA produkowanej przez Helico- } \\
\text { bacter pylori, indukującej śmierć komórek }\end{array}$ \\
\hline Adipocyty (3T3-L1) & $50 \mu \mathrm{M}$ & $\begin{array}{l}\text { Spadek transkrypcji lipazy za pośrednic- } \\
\text { twem FoxO1 }\end{array}$ \\
\hline $\begin{array}{l}\text { Ludzki nowotwór } \quad \text { wątroby } \\
\text { (HepG2) }\end{array}$ & $1-100 \mu \mathrm{M}$ & $\begin{array}{l}\text { Wzrost utleniania kwasów tłuszczowych, } \\
\text { zwiększenie aktywności AMPK }\end{array}$ \\
\hline Adipocyty & $\begin{array}{l}0,5-50 \mu \mathrm{M}+\text { kwas dokozaheksa- } \\
\text { enowy }\end{array}$ & $\begin{array}{l}\text { Spadek lipolizy podstawowej oraz marke- } \\
\text { rów stanu zapalnego }\end{array}$ \\
\hline $\begin{array}{l}\text { Linia komórkowa mysiego grasi- } \\
\text { czaka (EL4 T) }\end{array}$ & $2,5-5,0 \mu \mathrm{g} / \mathrm{mL}$ & Spadek IL-13 i IL-4 przez inhibicję GATA-2 \\
\hline $\begin{array}{l}\text { Linia komórkowa ludzkiego raka } \\
\text { jelita (HT-29) }\end{array}$ & $25 \mu \mathrm{M}$ & Spadek poziomu IL-8, azotynu oraz PGE2 \\
\hline $\begin{array}{l}\text { Linia komórkowa ludzkiego raka } \\
\text { jajnika (HO-8910PM) }\end{array}$ & $\mathrm{IC}_{50}, 13,8 \mu \mathrm{g} / \mathrm{mL}$ & $\begin{array}{l}\text { Wzrost apoptozy, } \\
\text { spadek ekspresji mucyny } 4\end{array}$ \\
\hline
\end{tabular}


Glikozyd-3-O-cyjanidyny przyczynia się do spadku poziomu cholesterolu i substancji reagujących $z$ kwasem tiobarbiturowym (ang. thiobarbituric acid reactive substances, TBARS) w błonach komórkowych erytrocytów u osób $z$ hipercholesterolemią. TBARS stanowia istotny parametr stosowany do badania peroksydacji lipidów w komórkach, ze względu na to, iż produkty wolnorodnikowego utleniania lipidów powoduja zmiany właściwości fizycznych błon komórkowych. Tak więc glikozyd cyjanidyny wpływa na zmniejszenie peroksydacji lipidów w błonach komórkowych erytrocytów, zaś obniżenie ilości cholesterolu pozwala na zwiększenie ich płynności (GROSICKA-MACIĄG 2011, DUCHNOWICZ i współaut. 2012). Z kolei w ludzkich adherentnych makrofagach z komórek U937 (modelowa linia komórkowa stosowana w badaniach biomedycznych), komórkach nabłonkowych jamy ustnej (GMSM-K) i ludzkich fibroblastach dziassła (HGF-1) zwiazek ten powoduje inhibicję wydzielania interleukiny 6 indukowanego przez lipopolisacharyd (zmniejsza reakcję zapalna) oraz neutralizuje cytotoksyczne działanie nikotyny na komórki nabłonka i fibroblasty, dzięki czemu może stanowić obiecujący środek prewencyjny lub leczniczy w choróbach przyzębia związanych $z$ paleniem papierosów (DESJARDINS i wpółaut. 2012). Helicobacter pylori charakteryzuje się wieloma czynnikami wirulencji. Jednym $z$ nich jest produkcja toksyny wakuolizujacej A (VacA), która prowadzi do uszkodzenia komórek nabłonka w żołądku. Badania wykazały, że C3G hamuje wydzielanie tej toksyny w zależności od zastosowanej dawki, poprzez inhibicję syntezy białka podjednostki A układu wydzielania (podjednostka A układu wydzielania, SecA), zwiazanego $z$ translokacja białek bakteryjnych. Zatem glikozyd-3-O-cyjanidyny przyczynia się do spadku śmiertelności komórek żoładka, spowodowanej działaniem $H$. pylori (KIM i współaut. 2014). W adipocytach (3T3-L1) glikozyd cyjanidyny prowadzi do osłabienia O-glikozylacji (stymulowanej przez glukozę) czynnika transkrypcyjnego FoxO1, co bezpośrednio wpływa na spadek ekspresji lipazy triglicerydów. Ten mechanizm świadczy o zdolności regulacji transkrypcji lipazy triglicerydów, a tym samym inhibicji lipolizy adipocytów za pośrednictwem czynnika FoxO1, co w przyszłości może mieć potencjalne zastosowanie $\mathrm{w}$ przypadku hiperlipidemii zwiazanej $\mathrm{z}$ cukrzyca (Guo i współaut. 2012a). Ponadto, Cy3G w połaczeniu $z$ kwasem dokozaheksaenowym powodował spadek lipolizy podstawowej, co także było zwiąane ze zmniejszeniem ekspresji lipazy triglicerydowej, w ekspresji której uczestniczy FoxO1. Dodatkowo, Cy3G zmniejszał poziom markerów stanu zapalnego (BJÖRK i współaut. 2016). W badaniu na linii komórkowej ludzkiego nowotworu wątroby glikozyd cyjanidyny prowadził do wzrostu aktywności kinazy białkowej aktywowanej przez AMP (AMPK) w sposób zależny od kinazy kalmodulinowej. Przyczyniał się także do stymulacji ekspresji palmitoilotransferazy karnitynowej I, co wpłynęło na znaczny wzrost utleniania kwasów tłuszczowych w komórkach HepG2 (linia komórkowa ludzkiego nowotworu wattroby). Wykazano, że Cy3G ma zdolność do regulacji homeostazy lipidów w watrobie poprzez szlak sygnałowy zależny od AMPK, co może dać możliwość zastosowania tego zwiąku w zapobieganiu i leczeniu niealkoholowej stłuszczeniowej choroby watroby zwiazanej $z$ otyłościa (GUO i współaut. 2012b). Sugeruje się, że chlorek glikozydu-3-O-cyjanidyny może mieć także zastosowanie jako środek przeciwalergiczny, ponieważ ma zdolność inhibicji specyficznego dla limfocytów T czynnika transkrypcyjnego GATA-3 w reakcjach alergicznych, jednocześnie prowadząc do hamowania ekspresji interleukin: IL-4 i IL-13 w limfocytach T, odgrywających kluczowa rolę w patogenezie różnych chorób alergicznych, takich jak atopowe zapalenie, astma czy alergiczny nieżyt nosa (PYO i współaut. 2014). Badanie linii komórkowej ludzkiego raka jelita miało na celu wykazanie ochronnego działania glikozydu-3-O-cyjanidyny przed reakcja zapalna wywołana przez cytokiny, w porównaniu ze znanym lekiem przeciwzapalnym - kwasem 5-aminosalicylowym. Wykazano, że glikozyd-3-O-cyjanidyny w warunkach in vitro efektywnie hamuje produkcję markerów prozapalnych: NO, PGE2 (prostaglandyna E2) i IL-8, indukowana przez cytokiny, a także powoduje inhibicję ekspresji iNOS (syntaza tlenku azotu) i cyklooksygenazy 2, przy znacznie niższym stężeniu niż kwas 5-aminosalicylowy, co sugeruje jego wyższa skuteczność przeciwzapalną (SERRA i współaut. 2013). ZENG i współaut. (2012) udowodnili, że C3G ma zdolność do inhibicji proliferacji komórek raka jajnika przy IC $_{50}$ (stężenie związku hamujace wzrost komórek w 50\%) wynoszacym około 13,8 mg/L, oraz wykazali wysoki wskaźnik apoptozy tych komórek i spadek ekspresji mucyny 4. Tak więc glikozyd-3-O-cyjanidyny charakteryzuje się aktywnościa przeciwnowotworowa w przypadku raka jajnika.

\section{KEMFEROL}

Cebula to bardzo cenne źródło składników odżywczych w diecie, w tym flawonoidów. Skład fitozwiązków różni się w zależności od odmiany, miejsca i sposobu uprawy, zaś zawartość flawonoidów jest inna w poszczególnych częściach cebuli; najbogat- 
sza w nie jest warstwa zewnętrzna (METRANI i wpspółaut. 2020). Jednym $z$ głównych związków występujących w cebuli jest kemferol (3,5,7-trihydroksy-2-(4-hydroksyfenylo)-4H-1-benzopiran-4-on), należący do flawonoli (MAKOWSKA-WĄS i JANECZKO 2004). Jego największa zawartościa charakteryzuje się warstwa zewnętrzna cebuli czerwonej i fioletowej. Jest to zwiazek o niskiej masie cząsteczkowej $(286,2$ g /mol) i żółtej barwie, który jest szeroko rozpowszechniony w przyrodzie; występuje w wielu roślinach i żywności pochodzenia roślinnego (CALDERÓNMONTAÑO i współaut. 2011). Wykazuje właściwości antyoksydacyjne. Dzięki obecności flawonoidów cebula charakteryzuje się wielokierunkowym działaniem, m.in.: przeciwutleniającym, przeciwnowotworowym, przeciwzakrzepowym, przeciwzapalnym, przeciwbakteryjnym, przeciwgrzybicznym, immunoprotekcyjnym, hepatoprotekcyjnym i neuroprotekcyjnym. Ponadto, może zapobiegać chorobom układu krażenia poprzez regulację poziomu lipidów we krwi oraz poprawę funkcji śródbłonka. Cebula podawana zwierzętom modelowym doustnie (dawka 50 $\mathrm{mg} / \mathrm{kg}$ masy ciała na dobę) wykazuje efekty terapeutyczne, jednak jej zbyt wysokie stężenie może przyczynić się do niekorzystnych zmian w organizmie (GALAVI i współaut. 2020). Kemferol ma potwierdzone właściwości antyoksydacyjne zarówno in vitro, jak $\mathrm{i}$ in vivo. Za jego aktywność przeciwutleniajaca odpowiada podwójne wiazanie w C2-C3, a także grupa OH w C3, C4' i C5, C7. Działanie antyoksydacyjne kemferolu zwiąane jest $z$ jego zdolnościa do zmiatania anionów ponadtlenkowych, rodnika hydroksylowego czy nadtlenoazotynu. Inne mechanizmy antyoksydacyjne kemferolu obejmuja: inhibicję aktywności enzymów stymulujących syntezę reaktywnych form tlenu, np. oksydazy ksantynowej, chelatowanie jonów żelaza $i$ miedzi oraz zwiększenie ekspresji enzymów antyoksydacyjnych, np. dysmutazy ponadtlenkowej czy katalazj. Zapobiega także peroksydacji lipidów i utlenianiu lipoprotein o małej gęstości (frakcja LDL cholesterolu), co ma chronić organizm przed wystapieniem miażdżycy. Antybakteryjne właściwości kemferolu zostały potwierdzone in vivo podczas badania mongolskich myszoskoczków, którym podano doustnie bakterię $H$. pylori. Po czterech tygodniach przyjmowania kemferolu (dwa razy na dobę przez 10 dni) zaobserwowano wyraźny spadek liczebności kolonii Helicobacter w żołąku zwierząt. Ponadto, kemferol wykazuje synergistyczne działanie z antybiotykami takimi jak: ryfampicyna, wankomycyna czy klindamycyna, w przypadku antybiotykoopornych szczepów bakterii (CALDERÓN-MONTAÑo i współaut. 2011).
Jako silny promotor apoptozy, ma zdolność do modyfikacji komórkowych szlaków sygnałowych, a jednocześnie wykazuje znacznie mniejszą toksyczność dla komórek prawidłowych, w porównaniu ze znanymi lekami chemioterapeutycznymi. Liczne badania potwierdziły, że dieta będąca źródłem kemferolu zmniejsza ryzyko wystapienia raka u osób palących papierosy, co związane jest $z$ przerwaniem przez kemferol szlaku receptora węglowodorów arylowych, aktywowanego przez czynniki rakotwórcze obecne np. w dymie papierosowym, przez zablokowanie wiazania receptora $z$ substancja mutagenna. Sugeruje się, że kemferol, bezpieczny i tani element diety, stanowi potencjalny środek w chemoprewencji raka jajnika. Aktywność przeciwnowotworowa kemferolu jest także związana $z$ poprawą biodostępności związków przeciwnowotworowych, ponieważ wykazuje on powinowactwo do białek transportowych - wiąże się $z$ nimi, zapobiegając wydaleniu chemioterapeutyków $z$ komórek nowotworowych (CHEN i CHEN 2013). Liczne badania in vitro $\mathrm{i}$ in vivo dowiodły, że kemferol, jego glikozydy oraz rośliny bogate w ten flawonoid, wykazuja działanie neuroprotekcyjne. Aktywność ta wiąże się ze zdolnościa do: zmniejszenia uszkodzeń niedokrwiennych mózgu poprzez inhibicję aktywności metaloproteinazy, zapobiegania akumulacji nitrotyrozyn oraz ochrony komórek przed stresem oksydacyjnym. Co więcej, kemferol może obniżać poziom $\beta$ amyloidu, co ma szczególne znaczenie w przypadku choroby Alzheimera (CALDERÓn-MontAÑo i współaut. 2011).

\section{KWERCETYNA}

Kwercetyna (3,3',4',5,7-pentahydroksyflawon) to szeroko rozpowszechniony fitozwiazek o udowodnionym działaniu prozdrowotnym, który należy do flawonoidów (grupa flawonoli), a jej źródłem jest m.in. czerwona cebula. Za bioaktywność odpowiada jej struktura chemiczna: obecność trzech pierścieni aromatycznych oraz pięć grup -OH. Optymalny zakres jej spożycia waha się od 25 do $35 \mathrm{mg}$ na dzień, a aglikonu kwercetyny jako suplementu diety $1 \mathrm{~g}$ na dobę. W produktach spożywczych kwercetyna zazwyczaj zwiazana jest $z$ innymi zwiazkami, często $\mathrm{w}$ postaci $\beta$-glikozydów połaczonych $\mathrm{np}$. $z$ rutynoza, ramnoza i glukoza (KoBYLIŃsKA i JANAS 2015, KAŁWA 2019). Zawartość glikozydów kwercetyny jest inna dla różnych odmian cebuli: w żółtej i czerwonej to od 25 do $65 \mathrm{~g} / \mathrm{kg}$, a w białej nieco mniej, około $10 \mathrm{mg} / \mathrm{kg}$. Nagromadzenie kwercetyny wzrasta $\mathrm{w}$ cebuli $\mathrm{w}$ kierunku od wewnętrznych do zewnętrznych liści. Jest ona jednym $z$ najsilniejszych przeciwutleniaczy pochodzenia roślinnego, a jej działanie opiera się na: 
- neutralizacji wolnych rodników (tlen singletowy, rodnik hydroksylowy, tlenek azotu i inne) w żywności i komórkach organizmu;

- inhibicji aktywności enzymów uczestniczacych w tworzeniu reaktywnych form tlenu;

- hamowaniu enzymatycznej peroksydacji fosfolipidów w błonie komórkowej;

- chelatowaniu jonów metali $\left(\mathrm{Fe}^{2+}, \mathrm{Cu}^{2+}\right)$;

- inhibicji aktywności oksydaz;

- modulacji katalizatorów biorących udział w procesach przeciwrodnikowych, takich jak: dysmutaza ponadtlenkowa czy transferaza glutationowa;

- zwiększaniu stabilności struktur komórkowych, przyczyniajac się do ich większej oporności na działanie czynników szkodliwych (KOBYLIŃSKA i JANAS 2015, KAEWA 2019).

Kwercetyna chroni neurony przed uszkodzeniami oksydacyjnymi i hamuje tworzenie się włókien $\beta$-amyloidu majacych znaczenie w rozwoju choroby Alzheimera. Obniża poziom cytokin prozapalnych, jednocześnie stymulujac regenerację komórek nerwowych. Reguluje także ekspresję cyklooksygenazy 2, wpływajac na procesy zapalne. Badania na mysim modelu wykazały, że długotrwała suplementacja kwercetyny zmniejsza dysfunkcję mitochondriów poprzez przywracanie potencjału błony mitochondrialnej, obniża synteze reaktywnych form tlenu oraz stymuluje syntezę ATP. Badania in vitro wykazały, że jej aktywność antyoksydacyjna zależy od zastosowanego stężenia; ma działanie terapeutyczne na neurony wyłacznie w niskich stężeniach (5 i $10 \mu \mathrm{M}$ ) (KHAN i współaut. 2019). Kwercetyna działa antybakteryjnie poprzez inhibicje wzrostu $H$. pylori, co ma istotne znaczenie w prewencji i leczeniu wrzodów żołądka spowodowanych ta bakterią. Natomiast jej działanie przeciwwirusowe pozwala na przyłaczanie się do białek w płaszczu wirusa HIV, a tym samym dezaktywację DNA wirusa, a także na ograniczenie przedostawania się czastek wirusa HIV-1 do limfocytów CD4 oraz hamowanie działania odwrotnej transkryptazy (KAŁWA 2019). Kwercetyna wykazuje także właściwości przeciwnowotworowe przez:

- blokowanie proliferacji komórek nowotworowych w fazie G1 i G2/M, wpływajac na białka regulatorowe, np. cykliny czy kinazy cyklinozależne;

- inhibicję ekspresji białek szoku cieplnego, których nadekspresja w komórkach nowotworowych zapewnia im oporność na chemioterapeutyki (kwercetyna prowadzi do zwiększenia ich wrażliwości na leki przeciwnowotworowe);
- regulacje poziomu ekspresji białek $Z$ rodziny Bcl-2 (reguluja uwalnianie cytochromu c z mitochondriów), należących do protoonkogenów;

- działanie synergistyczne $z$ innymi zwiazkami (np. cytostatykami), co powoduje nasilenie aktywności przeciwnowotworowej;

- aktywność ochronna wobec komórek prawidłowych, niezmutowanych.

Kwercetyna, dzięki aktywności proapoptotycznej wobec komórek zmienionych nowotworowo, ma obiecujacy potencjał terapeutyczny i być może w przyszłości znajdzie zastosowanie jako skuteczny lek przeciwnowotworowy (KOBYLIŃSKA i JANAS 2015).

\section{FITOZWIAZKI CZOSNKU - ALLINA, ALLICYNA I AJOEN}

Czosnek pospolity ze względu na bogactwo związków o dużej aktywności biologicznej nazywany jest ,,naturalnym antybiotykiem". Jedna $z$ głównych substancji biologicznych $\mathrm{w}$ tym surowcu jest allina (sulfotlenek S-allilocysteiny) - siarkoorganiczny zwiazek chemiczny (CHLEBDA-SIERAGOWSKA i współaut. 2012). Obróbka mechaniczna czosnku powoduje katalityczny rozkład alliny przez allinaze do m.in. allicyny i ajoenu (tiosulfinian dialilu). Wszystkie te zwiazki zawierają w swojej budowie siarkę. Czosnek, nawet $\mathrm{w}$ niskich stężeniach, działa antybakteryjnie, także na szczepy antybiotykooporne; najsilniej oddziałuje na bakterie beztlenowe, mniejsza aktywność wykazuje wobec tlenowych bakterii Gram-dodatnich i Gram-ujemnych, wykazuje także właściwości grzybobójcze (CHLEBDA-SiERAGOWSKA i współaut. 2012, TADEUSIEWICZ i współaut. 2014, MATYSIAK i współaut. 2015). Allicyna należy do aminokwasów i odpowiada za ostry zapach i smak czosnku. Charakteryzuje się działaniem przeciwzakrzepowym, przeciwmiażdżycowym, przeciwnowotworowym, obniżajacym ciśnienie krwi i poziom tłuszczów w surowicy, a dzięki zdolności do przenikania przez błone komórkowa ma istotne znaczenie w przebiegu reakcji biochemicznych (TADEUSIEWICZ i współaut. 2014, MATYSIAK i współaut. 2015). Zwiazki czosnku wykazują działanie antyagregacyjne płytek krwi, co najprawdopodobniej zwiazane jest $z$ inhibicja syntezy tromboksanu, na skutek zahamowania działania cyklooksygenazy. W badaniu przeprowadzonym na grupie pacjentów $z$ choroba wieńcową zaobserwowano, iż po dwóch tygodniach suplementacji ekstraktem z czosnku wzrosło rozszerzenie śródbłonka zależne od przepływu krwi w tętnicy ramiennej oraz zmniejszył się poziom interleukiny-6 (WILLIAMS i współaut. 2005). LIS i współaut. (2013) wykazali, że stosowanie $250 \mathrm{mg} /$ 
Tabela 2. Efekty suplementacji czosnku, podawanego w różnej postaci, u osób ze schorzeniami sercowo-naczyniowymi (LIS i współaut. 2013). Zmodyfikowano.

\begin{tabular}{|c|c|c|c|}
\hline Preparat & Badani & $\begin{array}{l}\text { Dawka i czas trwania su- } \\
\text { plementacji }\end{array}$ & Efekty \\
\hline Surowy czosnek & $\begin{array}{l}30 \text { dorosłych osób } \mathrm{z} \text { hi- } \\
\text { percholesterolemią }\end{array}$ & 10 g/d. przez $42 \mathrm{dni}$ & $\begin{array}{l}\text { Spadek poziomu cCh i TG; } \\
\text { wzrost poziomu HDL }\end{array}$ \\
\hline Czosnek w proszku & $\begin{array}{l}51 \text { osób z chorobą układu } \\
\text { krążenia } \\
42 \text { mężczyzn z łagodną hi- } \\
\text { percholesterolemia }\end{array}$ & $\begin{array}{l}300 \mathrm{mg} / \mathrm{d} . \text { przez } 12 \mathrm{mie}- \\
\text { sięcy } \\
600 \mathrm{mg} / \mathrm{d} \text {. przez } 12 \mathrm{mie}- \\
\text { sięcy }\end{array}$ & $\begin{array}{l}\text { Spadek poziomu cCh i LDL } \\
\text { Spadek poziomu cCh i LDL, } \\
\text { wzrost poziomu HDL }\end{array}$ \\
\hline Ekstrakt czosnku & $\begin{array}{l}23 \text { osoby dorosłe } z \text { hiper- } \\
\text { cholesterolemia, w tym } 13 \\
\text { z nadciśnieniem }\end{array}$ & $\begin{array}{l}\text { ok. } 10 \mathrm{~g} / \mathrm{d} . \text { przez } 4 \text { mie- } \\
\text { siące }\end{array}$ & $\begin{array}{l}\text { Spadek poziomu cCh, LDL i } \\
\text { TG; } \\
\text { wzrost poziomu HDL; } \\
\text { spadek ciśnienia skurczowego } \\
\text { i rozkurczowego krwi }\end{array}$ \\
\hline Olej czosnkowy & 20 osób z nadciśnieniem & $\begin{array}{l}250 \mathrm{mg} / \mathrm{d} \text {. przez } 2 \mathrm{mie}- \\
\text { siące }\end{array}$ & $\begin{array}{l}\text { Spadek ciśnienia skurczowego } \\
\text { i rozkurczowego krwi; } \\
\text { spadek poziomu oxLDL }\end{array}$ \\
\hline Macerat czosnkowy & $\begin{array}{l}70 \text { dorosłych osób } z \text { nad- } \\
\text { ciśnieniem }\end{array}$ & 1620 mg/d. przez 30 dni & $\begin{array}{l}\text { Spadek poziomu cCh, LDL i } \\
\text { TG }\end{array}$ \\
\hline
\end{tabular}

cCh - choleteserol całkowity; LDL - lipoproteiny o niskiej gęstości, oxLDL - oksydowane lipoproteiny o niskiej gęstości, HDL - lipoproteiny o wysokiej gęstości, TG - triglicerydy

dzień oleju z czosnku przez okres dwóch tygodni powodowało spadek skurczowego i rozkurczowego ciśnienia krwi u osób z nadciśnieniem. Skutki suplementacji czosnku u osób z chorobami układu krążenia przedstawiono w Tabeli 2 .

Badania kliniczne osób przyjmujacych sproszkowany czosnek, zawierajacy 1,3\% alliny $\mathrm{w}$ dawce 600-900mg na dobe przez około trzy miesiace, wykazały spadek skurczowego ciśnienia tętniczego krwi o $11 \mathrm{mmHg}$ oraz ciśnienia rozkurczowego o $5 \mathrm{mmHg}$ (GAJDA 2019). Obecne w wyciagu $z$ czosnku zwiazki siarkowe, m.in. allicyna, maja zdolność inhibicji aktywacji czynnika NF-kB (np. $\mathrm{w}$ makrofagach), bioracego udział w transkrypcji wielu genów związanych $z$ reakcja zapalną (Lis i współaut. 2013). Natomiast ajoen, który powstaje na skutek samokondensacji allicyny, stanowi główny składnik ekstraktu eterowego $z$ czosnku. Hamuje on agregację płytek krwi, a także charakteryzuje się aktywnością przeciwwirusowa i dlatego czosnek może być skutecznym środkiem przeciwko wirusowi opryszczki, HIV, wirusowi wywołującemu cytomegalię i wirusowemu zapaleniu płuc (LUTOMSKI 2001, LIS i współaut. 2013, TADEUSIEWICZ i współaut. 2014). W badaniu na komórkach wątroby szczurów potraktowanych ajoenem zaobserwowano spadek produkcji cholesterolu o 18\%. Natomiast w ludzkich komórkach HepG2, zarówno ajoen, jak i allicyna, istotnie obniży- ły syntezę cholesterolu - odpowiednio o 19 i $18 \%$ (LIS i współaut. 2013). Wyizolowany $z$ ekstraktu czosnkowego ajoen wykazuje in vitro synergistyczne działanie przeciwbakteryjne $z$ tobramycyna, powodujacc obniżenie żywotności bakterii Pseudomonas aeruginosa w biofilmie. Badania JAKOBSENA i współaut. (2012) na myszach $z$ zakażeniem płuc wykazały eliminację infekcji $P$. aeruginosa pod wpływem ajoenu, co potwierdziło jego antybakteryjne działanie. Ostatnio popularność zyskał czosnek niedźwiedzi, który zawiera dużą ilość związów siarki, m.in. allinę i allicynę, przy czym zawartość alliny w świė̇ych liściach wynosi od 0,25 do $1,15 \%$, zaś w materiale suszonym w umiarkowanych warunkach jej ilość nie przekracza 2\%. Skład chemiczny powoduje, że czosnek niedźwiedzi wykazuje szereg właściwości prozdrowotnych: łagodzi zatrucia metalami ciężkimi, zapobiega nadmiernej agregacji płytek krwi, rozrzedza krew i ulepsza jej przepływ w naczyniach krwionośnych. Pomaga także w leczeniu chorób skóry, np. trądziku, a także ma korzystny wpływ na regenerację flory bakteryjnej po antybiotykoterapii. Co więcej, wodne ekstrakty jego świeżych liści charakteryzuja się działaniem antybakteryjnym wobec takich szczepów bakterii jak: Salmonella enteritidis, Pseudomonas aeruginosa czy Escherichia coli, oraz przeciwko drożdżom: Candida albicans i Saccharomyces cerevisiae (DŻUGAN i współaut. 2014). Badania przepro- 
wadzone przez BERETTA i współaut. (2017) na sześciu warzywach $z$ rodzaju Allium (czosnek, cebula, cebula siedmiolatka, por, szczypiorek, szalotka) wykazały, że wszystkie maja aktywność antypłytkowa, a najsilniejsze zdolności antyagregacyjne wykazywał czosnek. Jest to najprawdopodobniej zwiazane $z$ obecnościa wielu zwiazków fenolowych i związków siarki, które poza właściwościami przeciwpłytkowymi, wykazuja zdolności antybakteryjne i grzybobójcze.

\section{LIKOPEN - NAJWAŻNIEJSZY ZWIĄZEK OBECNY POMIDORZE}

Istotnym związkiem, wchodzacym w skład pomidora i innych czerwonych warzyw i owoców, jest likopen ( $\psi, \psi$-karoten), należacy do grupy karotenoidów, o udowodnionych ( $\mathrm{w}$ badaniach in vitro $\mathrm{i}$ in vivo) właściwościach prozdrowotnych. Na skład chemiczny pomidorów bezpośrednio wpływaja warunki uprawy i faza rozwoju owoców. Optymalna temperatura dla syntezy likopenu mieści się w zakresie $16-22^{\circ} \mathrm{C}$, zaś jej gwałtowny wzrost prowadzi do tworzenia $z$ likopenu $\beta$-karotenu. Przypuszcza się, że gotowanie dojrzałych pomidorów sprzyja zwiększeniu biodostępności karotenoidów, a ich ilość jest większa w przetworach (przeciery, koncentraty, sosy, zupy) niż w surowych owocach. Jest to skorelowane $z$ wydzielaniem likopenu ze skórek podczas obróbki termicznej i przekształcaniem formy trans- do cis-likopenu. $Z$ kolei suszone pomidory odznaczaja się wysoka zawartościa witamin: $\mathrm{C}, \mathrm{A}, \mathrm{B}_{1}$, $\mathrm{B}_{2}, \mathrm{~B}_{6}$ (STORY i współaut. 2010, ZDROJEWICZ i współaut. 2016, GwóŹDŹ i GEBCZYŃSKI 2017). Zawartość likopenu w różnych produktach na bazie pomidorów przedstawiono w Tabeli 3.

Likopen to wielonienasycony węglowodór, tetraterpen, zawierający 11 sprzężonych i 2 nieskoniugowane podwójne wiazania w łańcuchu alkilowym (STORY i współaut. 2010, GwÓŹDŹ i GĘBCZYŃSKI 2017). Uważa się, że taka struktura decyduje o jego właściwościach antyoksydacyjnych; posiada zdolność eliminacji tlenu singletowego dwukrotnie większa niż $\beta$-karoten i dziesięciokrotnie większa niż a-tokoferol. Ponadto, charakteryzuje się stukrotnie większą aktywnościa przeciwutleniajacca $\mathrm{w}$ porównaniu do witaminy E i C (ANTARTANI i ASHOK 2011, SKIEPKO i współaut. 2015). Likopen roślinny występuje zazwyczaj jako izomer trans. Izomeryzacja izomeru trans do bardziej biodostępnego izomeru cis zachodzi w warunkach kwaśnych (np. kwasu żoładkowego) oraz w wyniku ekspozycji na światło i energię cieplna (Mozos i współaut. 2018). Jedną $z$ głównych właściwości karotenoidów jest działanie an-
Tabela 3. Zawartość likopenu w wybranych produktach pomidorowych (SKIEPKO i współaut. 2015). Zmodyfikowano.

\begin{tabular}{lll}
\hline Rodzaj produktu & $\begin{array}{l}\text { Zawartość } \\
{[\mathrm{mg} / 100 \mathrm{~g} \text { ś.m. }]}\end{array}$ & likopenu \\
\hline Pomidor świeży & $0,72-4,2$ \\
Pomidor gotowany & 3,7 \\
Sok pomidorowy & $5,0-11,6$ \\
Sos pomidorowy & 6,2 \\
Koncentrat pomidorowy & $5,4-150$ \\
Zupa pomidorowa & 7,99 \\
Proszek pomidorowy & $112,6-265$ \\
Sos pomidorowy do pizzy & 12,7 \\
Ketchup pomidorowy & $9,9-13,4$ \\
\hline
\end{tabular}

tyoksydacyjne, które znalazło zastosowanie w protekcji i leczeniu m.in. miażdżycy, schorzeń zwiazanych $z$ narządem wzroku, nowotworów szyjki macicy i gruczołu sutkowego u kobiet oraz prostaty, za co w dużej mierze odpowiada likopen (GwÓŹDŹ i GEBCZYŃSKI 2017). Funkcja likopenu jest neutralizacja rodnika hydroksylowego, dwutlenku azotu (które przyczyniaja się do niekorzystnych zmian w limfocytach) i rodnika tiolowego, a także zapobieganie utlenianiu białek, DNA, lipidów i frakcji LDL cholesterolu (WIKTOROWSKA-OWCZAREK 2013). Chroni także przed niekorzystnymi zmianami mitochondriów i komórek śródbłonka wywołanymi przez stres oksydacyjny. Ponadto, ma zdolność do modulacji produkcji enzymów antyoksydacyjnych, np. dysmutazy ponadtlenkowej i katalazy. Likopen odgrywa także ważna rolę $\mathrm{w}$ łagodzeniu skutków wystapienia stresu oksydacyjnego u osób palacych - stanowi jeden $z$ głównych karotenoidów zmniejszajacych ryzyko miażdżycy u obecnych i byłych palaczy (Mozos i współaut. 2018). Co więcej, likopen pozwala na eliminację ognisk przerzutowych oraz inhibicję namnażania komórek nowotworowych (GwóźDź i GĘBCZYŃSKI 2017). Spożywanie pomidorów pozwala także na obniżenie poziomu cholesterolu we krwi, a także zminimalizowanie ryzyka wystapienia chorób sercowo-naczyniowych, ze względu na istotny spadek podatności frakcji LDL cholesterolu na utlenianie, co świadczy o działaniu kardioochronnym (ZDROJEwICZ i współaut. 2016, GwóźDź i GEBCZYŃSKI 2017). Tak więc, likopen przyczynia się do pierwotnej i wtórnej profilaktyki chorób sercowo-naczyniowych. 
Główne mechanizmy działania likopenu obejmują aktywność przeciwmiażdżycowa, przeciwutleniajaca, przeciwzapalna, przeciwnadciśnieniowa, przeciwpłytkowa, przeciwapoptotyczna, działanie ochronne na śródbłonek oraz zdolność do zmniejszenia sztywności tętnic. Aktywność przeciwpłytkowa chroni przed wystapieniem zawału serca i udaru, ale w dużej mierze zależy od zastosowanego stężenia. Mechanizm tego działania jest ściśle związany ze zdolnością tego karotenoidu do interakcji m.in. $z$ tromboksanem, trombina, kolagenem, czynnikiem von Willebranda, selektyna $\mathrm{P}$ i mediatorami zapalenia. Zaobserwowano także, że likopen może nasilać przeciwpłytkowe działanie aspiryny. Spożywanie co najmniej 7 porcji produktów (m.in. pomidorów) na bazie likopenu w ciagu tygodnia znacznie zmniejszyło ryzyko wystapienia chorób sercowo-naczyniowych w ciagu siedmiu lat $u$ kobiet po menopauzie, nie cierpiących wcześniej na zaburzenia sercowo-naczyniowe ani na raka (Mozos i współaut. 2018). Badania przeprowadzone na kobietach w ciąży wykazały, że suplementacja likopenem istotnie wpłynęła na zmniejszenie częstości występowania wewnattrzmacicznego ograniczenia wzrostu płodu i pozwoliła uzyskać ogólne lepsze wyniki okołoporodowe, w porównaniu $z$ grupa kontrolna nie przyjmująca tego suplementu (ANTARTANI i ASHOK 2011). Sugeruje się, że likopen może mieć działanie neuroprotekcyjne w ośrodkowym układzie nerwowym (OUN). Hipoteze tę potwierdzają niektóre wcześniejsze badania dotyczące jego roli w ograniczeniu zaburzeń neurodegeneracyjnych i psychiatrycznych. Wykazano, że suplementacja likopenem może poprawić zdolności poznawcze u myszy transgenicznych i osłabić toksyczność komórkowa indukowana $\beta$ amyloidem w hodowanych neuronach. Opisano także zdolność likopenu do inhibicji zaburzeń funkcji poznawczych i motorycznych w przypadku choroby Huntingtona, spowodowanych przez kwas 3-nitropropionowy. Likopen może również stanowić potencjalny środek przeciwdepresyjny, będacy skuteczna alternatywą dla znanych leków na tę chorobę, co może być skorelowane $z$ jego przeciwzapalnym wpływem na komórki układu nerwowego (CHEN i współaut. 2019). Pomidor oraz produkty otrzymywane $z$ jego owoców stanowia ważny element diety człowieka ze względu na obecność związków mających znaczenie prozdrowotne, głównie karotenoidów, w tym likopenu. Pozwalaja na obniżenie częstości występowania chorób sercowo-naczyniowych i nowotworów (GwóźDź i GËBCZYN̂SKI 2017).

\section{GINGEROLE - ZWIAZKI OBECNE W IMBIRZE}

Imbir jest źródłem zwiazków bioaktywnych, w tym fitoskładników, takich jak związki lotne (np. kamfen, linalool, cineol) i nielotne (np. shogaole, zingerony). Jedna $z$ najważniejszych substancji obecnych w imbirze sa gingerole (np. 6-gingerol, 10-ginegrol), grupa związków charakteryzujących się budowa fenolowa $z$ łańcuchami bocznymi o różnej długości. Występuja w ilości od 4 do $7,5 \%$ masy surowca $i$ to one w głównej mierze decyduja o ostrym smaku kłącza imbiru (ŁAŻEWSKA i współaut. 2019). Wyróżnia je nietrwałość termiczna w roztworach wodnych; na skutek dehydratacji tworza wówczas shogaole. Gingerole i shogaole nadaja imbirowi właściwości farmakologiczne (AKBAR 2020). Działa on: przeciwbakteryjnie, przeciwwirusowo, przeciwbólowo, przeciwzapalnie, antyoksydacyjnie, przeciwgoraczkowo, przeciwnowotworowo, przeciwhiperglikemicznie i przeciwlipidemicznie. Dzięki szerokiej aktywności znalazł zastosowanie w leczeniu niestrawności, wzdęć, nudności, wrzodów, a także w przypadku zapalenia stawów i zapalenia płuc (ŁAŻEWSKA i współaut. 2019, ABDUlWASE i współaut. 2020). Eksperymentalnie wykazano, że imbir przyczynia się do pobudzenia produkcji kwasu żółciowego przez watrobę oraz aktywności lipazy trzustkowej, dzięki czemu powoduje nasilenie procesu trawienia i wchłaniania tłuszczów przy stosowaniu diety wysokotłuszczowej, a także do wzrostu aktywności takich enzymów jak trypsyna czy chymotrypsyna. Badania przeprowadzone na myszach pozwoliły wykazać, iż suplementacja imbirem przyczynia się do kształtowania flory jelitowej, większej liczebności bakterii rodzaju Bifidobacterium oraz m.in. Allobaculum wytwarzajacych krótkołańcuchowe kwasy tłuszczowe. Z kolei doswiadczenia na szczurach dowiodły, iż podawanie imbiru przyczyniło się do wzrostu powierzchni jelita cienkiego, odpowiadajacej za wchłanianie pokarmu oraz zwiększenia przyswajalność żelaza, cynku i wapnia, co pozwala wywnioskować, iż imbir ma działanie protekcyjne na przewód pokarmowy. $\mathrm{Za}$ zdolności przeciwrodnikowe imbiru odpowiadaja m.in. flawonoidy, kwasy fenolowe i polifenole. Do naturalnych przeciwutleniaczy należy także 6-gingerol, który stanowi istotny inhibitor syntezy tlenku azotu i ma właściwości ochronne wobec makrofagów przed szkodliwym wpływem nadtlenoazotynu. Działanie antyoksydacyjne imbiru polega na neutralizacji wolnych rodników w organizmie, inhibicji peroksydacji lipidów oraz utleniania frakcji LDL cholesterolu, wspomaganiu enzymów antyoksydacyjnych oraz 
endogennych przeciwutleniaczy (KIELISZEK i współaut. 2020). KIELISZEK i współaut. (2020) wykazali, że wodny ekstrakt imbiru ma zdolność redukcji jonu żelaza III do jonów żelaza II oraz zmiatania DPPH (2,2-difenylo-1-pikrylohydrazyl). Badania ŁAŻEWSKIEJ i współaut. (2019) dowiodły, że imbir, dzięki zawartości m.in. 6-ginegorlu i 6-shogaolu, ma istotne znaczenie $\mathrm{w}$ prewencji raka przewodu pokarmowego, co jest ściśle zwiąane z modulacja czasteczek sygnałowych [NF-kB (czynnik jadrowy kappa B), TNF-a (czynnik martwicy nowotworów) czy COX-2 (cyklooksygenaza 2)]. 6-gingerol stanowi także silny inhibitor syntetazy prostaglandyn in vitro. Wodny ekstrakt $z$ imbiru $w$ zależności od stężenia wpływał na inhibicję agregacji płytek krwi indukowana in vitro przez ADP, adrenalinę, kolagen i kwas arachidonowy (IMTIYAZ i współaut. 2013). W badaniu, w którym grupie osób przez ponad 12 tygodni podawano suplementy imbiru (3 kapsułki, każda zawierająca $500 \mathrm{mg}$ sproszkowanego surowca) wykazano, że poziom aminotransferazy alaninowej, cholesterolu całkowitego i frakcji LDL we krwi na czczo, wskaźnika insulinooporności, białka C-reaktywnego w surowicy oraz fetuiny-A znacznie spadła w porównaniu $z$ kontrola. $\mathrm{Na}$ podstawie otrzymanych wyników można wywnioskować, że suplement imbiru może być stosowany jako terapia uzupełniajaca $\mathrm{w}$ celu zmniejszenia insulinooporności, enzymów wątrobowych i stanów zapalnych u pacjentów $z$ niealkoholowym stłuszczeniem wątroby (RAFIE i współaut. 2020). 6-gingerol stanowi niezwykle istotny zwiazek antyoksydacyjny, który pełni ważna rolę $\mathrm{w}$ inhibicji transformacji, hiperproliferacji i procesów zapalnych, determinujacych końcowe etapy nowotworzenia, tworzenia się naczyń włosowatych i powstawania przerzutów. Jego działanie opiera się na aktywacji szlaku VEGF (czynnik wzrostu śródbłonka naczyniowego, odgrywajacy rolę w rozwoju i progresji nowotworu) i podwyzszeniu poziomu genów supresorowych, działających hamujaco na procesy proliferacji komórkowej. 6-gingerol może także modulować białka adhezyjne oraz hamować migrację różnych rodzajów komórek nowotworowych. Dzięki tak różnokierunkowym właściwościom, dobrej dostępności i korzystnej cenie, imbir stanowi potencjalny środek do wspomagania leczenia onkologicznego $i$ innych schorzeń (SKOTNICKA i współaut. 2017).

$$
\text { Streszczenie }
$$

Fitozwiazki to substancje chemiczne produkowane przez rośliny, wykazujące aktywność biologiczna i charakteryzujące się cennymi dla człowieka właściwościami prozdrowotnymi. Ze względu na szerokie zastosowanie, dobra dostępność i niska cenę stanowia ważne komponenty suplementów diety, podawane w odpowiednio dobranej dawce, w różnej formie. Dzięki wartościom terapeutycznym są celem licznych badań i moga mieć znaczenie jako potencjalne leki przeznaczone do walki $z$ chorobami o różnym podłożu.

\section{LITERATURA}

ABdulwase R., ABbas A. B., Yan S., 2020. Ginger as a commercial product in China. MOJ Biol. Med. 5, 1-2.

AKBAR S., 2020. Zingiber officinale Rosc. (Zingiberaceae). Handbook of 200 Medical Plants. Springer, Cham., doi.org/10.1007/978-3-03016807-0_199.

ANTARTANI R., ASHOK K., 2011. Effect of lycopene in prevention of preeclampsia in high risk pregnant women. J. Turkish-German Gynecol. Assoc. 12, 35-38.

Belter A., Giel-Pietraszuk M., Oziewicz S. CHOMCZYŃSKI P., BARCISZEWSKI J., 2011. Likopen - wystepowanie, właściwości oraz potencjalne zastosowanie. Post. Bioch. 57, 372380.

Beretta H. V., Bannoud F., Insani M., Berli F., Hirschegger P., Galmarini C. R., Cavagnaro P. F., 2017. Relationships between bioactive compound content and the antiplatelet and antioxidant activities of six allium vegetable species. Food Technol. Biotechnol. 55, 266-275.

BJöRK C., WILHELM U., MANDRUP S., LARSEN B. D., BORdoni A., HEDÉn P., RYdén M., ARNER P., LAURENCIKIENE J., 2016. Effects of selected bioactive food compounds on human white adipocyte function. Nutrit. Metabol. 13, 1-10.

CALDERÓN-MONTAÑO J. M., BuRgos-Morón E. PÉREZ-Guerrero C., LOPÉZ-LắZARO M., 2011. A review on the dietary flavonoid kaempferol. Mini-Rev. Med. Chem. 11, 298-344.

Chen A. Y., Chen Y. C., 2013. A review of the dietary flavonoid, kaempferol on human health and cancer chemoprevention. Food Chem. 138, 2099-2107.

Chen D., Huang C., Chen Z., 2019. A review for the pharmacological effect of lycopene in central nervous system disorders. Biomed. Pharmacother. 111, 791-801.

Chlebda-Sieragowska E., Skrezypiec-Spring M., SZELAG A., 2012. Rola preparatów ziołowych $w$ profilaktyce infekcji u sportowców. Strzelectwo Sportowe 9, 35-40.

DESJARDINS J., TANABE S., BERgeron C., GAFNER S., GRENIER D., 2012. Anthocyanin-rich black currant extract and cyanidin-3-O-glucoside have cytoprotective and anti-inflammatory properties. J. Med. Food 15,1045-1450.

DuCHNOWICZ P., BRONCEL M., PODSEDEK A., KoTER-MICHALAK M., 2012. Hypolipidemic and antioxidant effects of hydroxycinnamic acids, quercetin, and cyanidin 3-glucoside in hypercholesterolemic erythrocytes (in vitro study). Eur. J. Nutrit. 51, 435-443.

DŻUGAN M., KORDIAKA R., KAcắNIOVắ M., WESOŁOWSKA M., 2014. Czosnek niedźwiedzi (Allium ursinum) jako uzupełnienie wiosennej diety. [W:] Właściwości produktów i surowców żywnościowych. Wybrane zagadnienia. TARKO T., DUDA-CHODAK A. WITCZAK M., NAJGEBAUER-LEJKO D. (red.). Kraków, Oddz. Małopolski PTTŻ, Uniw. Roln., pp. 248-258.

GAJDA E., 2019. Fitoterapia $i$ dieta $w$ zapobieganiu $i$ leczeniu nadciśnienia tętniczego. Post. Fitoterap. 20, 73-80.

Galavi A., HosseinzadeH H., RazaVi B. M., 2020. The effects of Allium cepa L. (onion) and its 
active constituents on metabolic syndrome: A review. Iranian J. Basic Med. Sci. 23, 1-14.

GHERIBI E., 2011. Zwiazki polifenolowe $w$ owo cach $i$ warzywach. Medycyna Rodzinna 4, 111-115.

GrosicKA-MACIAGG E., 2011. Biologiczne skutki stresu oksydacyjnego wywołanego działaniem pestycydów. Post. Hig. Med. Dośw. 65, 357366.

Guo H., Guo J., Jiang X., Li Z., Ling W., 2012a. Cyanidin-3-O- $\beta$-glucoside, a typical anthocy anin, exhibits antilipolytic effects in 3T3-L1 adipocytes during hyperglycemia: Involvement of FoxO1-mediated transcription of adipose triglyceride lipase. Food Chem. Toxicol. 50, 3040-3047.

Guo H., LiU G., Zhong R., Wang Y., WANG D., XIA M., 2012b. Cyanidin-3-O- $\beta$-glucoside regulates fatty acid metabolism via an AMP-activated protein kinase-dependent signaling pathway in human HepG2 cells. Lipids Health Disease 11, 1-13.

GwÓŹDŹ E., GĘBCZYŃSKI P., 2017. Owoce pomidora źródłem karotenoidów. Medycyna Rodzinna 20, 211-214.

IMTIYAZ S., RAHEMAN K., Sultana A., 2013. Zingiber officinale Rosc.: A traditional herb with medicinal properties. TANG 3, 1-7.

JAKOBSEN T. H., VAN GENNIP M., PHIPPS R. K. i współaut., 2012. Ajoene, a sulfur-rich molecule from garlic, inhibits genes controlled by quorum sensing. Antimicrob. Agents Chemoth. 56, 2314-2325.

KAŁWA K., 2019. Właściwości antyoksydacyjne flawonoidów oraz ich wpływ na zdrowie człowieka. Kosmos 68, 153-159.

Khan H., Ullah H., Aschner M., Cheang W. S., AKKOL E. K., 2019. Neuroprotective effects of quercetin in Alzeimer's Disease. Biomolecules 10, 59-79.

KieliszeK M., EdRIS A., Kot A. M., PIWOWAREK K., 2020 Biological activity of some aromatic plants and their metabolites, with an emphasis on health-promoting properties. Molecules $25,1-20$.

Kim S. H., Woo H., Park M., RheE K. J., MoON C., LEE D., SEO W. D., KIM J. B., 2014. Cyanidin 3-O-glucoside reduces Helicobacter pylori VacA-induced cell death of gastric KATO III cells through inhibition of the SecA pathway. Int. J. Med. Sci. 11, 742-747.

KLEPACKA A. 2013. Przeciwglikacyjne właściwości ekstraktów roślinnych bogatych $w$ polifenole. Post. Fitoterap. 2, 127-131.

KoBYLIŃSKA A., JANAS K. M., 2015. Prozdrowotna rola kwercetyny obecnej $w$ diecie człowieka. Post. Hig. Med. Dośw. 69, 51-62.

Koche D., ShIRSAT R., KaWAlE M., 2016. An overview of major classes of phytochemicals: their types and role in disease prevention. Hislopia J. 9,1-11.

KosS-MiKoŁAJCZYK I., BARTOSZEK A., 2019. Bioaktywne fitozwiazki $w$ chemoprewencji przewlekłych chorób niezakaźnych - owoce $i$ warzywa czy suplementy diety? Żywność Nauka Technologia Jakość 26, 5-14.

LAWSON L. D., HunsaKer S. M., 2018. Allicin bioavailability and bioequivalence from garlic supplements and garlic foods. Nutrients 10, 812861.

LIS I., BogdAŃsKI P., NowAK G., 2013. Zastosowanie czosnku $w$ profilaktyce chorób układu sercowo-naczyniowego. Forum Zaburzeń Metabolicznych 4, 210-215.

LUTOMSKI J., 2001. Fascynacja czosnkiem - wczoraj $i$ dziś. Post. Fitoterap. 1, 7-14.
ŁAŻEWSKA D., MiETKIEWSKA K., STUDZIŃSKA-SROKA E., 2019. Imbir lekarski - roślina o właściwościach neuroochronnych. Post. Fitoterap. 4, 268-276.

MAKOWSKA-WAS J., JANECZKO Z., 2004. Biodostępność polifenoli roślinnych. Post. Fitoterap. 3, 126-137.

MatysiaK M., Gawę-Beben K., RybczyńsKa K., GMiŃSKI J., SuRMA S., 2015. Porównanie wybranych właściwości biologicznych czosnku (Allium sativum L.), pochodzacego $z$ Polski $i$ Chin. Żywność Nauka Technologia Jakość 2, 160-169.

METRANi R., Singh J., ACHARYA P., JAYAPRAKASHA G. K., PATIL B. S., 2020. Comparative metabolomics profiling of polyphenols, nutrients and antioxidant activities of two red onion (Allium cepa L.) cultivars. Plants 9, 1077-1094.

Mozos I., Stoian D., CARABA A., Malainer C., HORBIAŃCZUK J. O., ATANASOV A. G., $2018 \mathrm{Ly}$ copene and vascular health. Front. Pharmacol. $9,521$.

NowAK G., 2009. Surowce roślinne stosowane $w$ chorobach układu krażenia $i$ serca. Herba Pol. $55,100-120$.

Olas B., 2018. Dietary supplements with antiplatelet activity: a solution for everyone? Adv. Nutrit. 9, 51-57.

Olas B., 2019. Anti-aggregatory potential of selected vegetables - promising dietary components for the prevention and treatment of cardiovascular disease. Adv. Nutrit. 10, 280-290.

OlęDZKA R., 2007. Nutraceutyki, żywność funkcjonalna - rola $i$ bezpieczeństwo stosowania. Bromatol. Chemia Toksykol. 40, 1-8.

OLIVAS-AGUIRRE F. J., RODRIGO-GARCIA J., DEL MARTINES-Ruiz N. R., CARDENAS-Robles A. I., MENDOZA-DiAZ S. O., AlvarEZ-PARIRILla E., GONZ $\square$ LEZ-Aguilar G. A., DE LA ROSA L. A., RAMOS-JIMÉNEZ A., WALL-MEDRANO A., 2016. Cyanidin-3-O-glucoside: physical-chemistry, foodomics and health effects. Molecules 21, 1-30.

OSTROWSKA M., KRZEWIŃSKI Z., 2017. Nowe leki roślinne. https://www.ncbr.gov.pl/potrzebuje-wiedzy-uczelniainstytut/sciezki-komercjalizacji-b-r/szczegoly/news/nowe-leki-roslinne-50179/.

PRokop P., Astel A., 2017. Rola suplementacji $w$ zbilansowanym żywieniu człowieka (Cz. I). Laboratoria Aparatura Badania 4, 46-51.

PYO M. Y., YOON S. J., YU Y., PARK S., JIN M., 2014. Cyanidin-3-glucoside suppresses Th2 cytokines and GATA-3 transcription factor in EL-4 T cells. Biosci. Biotechnol. Biochem. 78, 1037-1043.

Rafie R., Hosseini S. A., HaJiani E., SAKI Malehi A., MARD S. A., 2020. Effect of ginger powder supplementation in patients with non-alcoholic fatty liver disease: a randomized clinical trial. Clin. Exp. Gastroenterol. 23, 35-45.

RYK M., 2018. Izolowanie antocyjanów na drodze ekstrakcji z komórek kapusty głowiastej czerwonej (Brassica oleracea var. Capitata f. rubra), winogron (Vitis Vinifera subsp. Vinifera $i$ bakłażanów (Solanum melongena). Acta Juvenum 3, 109-115.

SALUK-JUSZCZAK J., 2010. Antocyjany jako składnik żywności funkcjonalnej stosowanej $w$ profilaktyce chorób układu krążenia. Post. Hig. Med. Dośw. 64, 451-458.

SCHLEGEL-ZAWADZKA M., BARTECZKO M., 2009. Ocena stosowania suplementów diety pochodzenia naturalnego $w$ celach prozdrowotnych przez osoby dorosłe. Żywność Nauka Technologia Jakość 4, 375-387. 
Serra D., PaixÃo J., Nunes C., Dinis T. C., AlMEIDA L. M., 2013. Cyanidin-3-glucoside suppresses cytokine-induced inflammatory response in human intestinal cells: Comparison with 5-aminosalicylic acid. PLoS One 8, doi: 10.1371/journal.pone.0073001.

Suantawee T., Thilavech T., Cheng H., AdisaKWATTANA S., 2020. Cyanidin Attenuates Methylglyoxal-Induced Oxidative Stress and Apoptosis in INS-1 Pancreatic $\beta$-Cells by Increasing Glyoxalase-1 Activity. Nutrients 12, 13191330.

SKIEPKO N., ChWASTOWSKA-SIWIECKA I., KONDRATOWICZ J., 2015. Właściwości likopenu $i$ jego wykorzystanie $w$ produkcji żywności funkcjonalnej. Żywność Nauka Technologia Jakość 6, 20-32.

SKOTNICKA M., Golan M., SzMUKaŁA N., 2017. Rola naturalnych przeciwutleniaczy pochodzenia roślinnego $w$ profilaktyce nowotworowej.
Ann. Academiae Medicae Gedanensis 47, 119-127

StORY E. N., Kopec R. E., Schwartz S. J., HARRIS G. K., 2010. An update on the health effects of tomato lycopene. Ann. Rev. Food Sci. Technol. 1, 189-210.

TADEUSIEWICZ J., KRYSZTOFIAK A., Olas B., 2014. Czosnek - panaceum na choroby układu krażenia? Kosmos 63, 37-44.

WikTOROWSKA-OWCZAREK A., 2013. Przeciwutleniajace właściwości pomidora (Lycopersicum esculentum L.). Post. Fitoter. 3, 195-199.

ZDROJEWICZ Z., PACHURA E., PACHURA P., 2016. Działanie lecznicze owoców pomidora zwyczajnego. Post. Fitoter. 17, 44-48.

ZENG L., GAO J., ZHANG R., 2012. Study on anti-tumor effect of cyanidin-3-glucoside on ovarian cancer. Zhongguo Zhong Yao Za Zhi 37, 1651-1654.

KOSMOS Vol. 70, 1, 103-114, 2021

Magdalena Ulanowska, Beata Olas

Department of General Biochemistry, Institute of Biochemistry, Faculty of Biology and Environmental Protection, University of Eódź, Pomorska 141/143, 90-236 Eódź, E-mail: magdalena.ulanowska@edu.uni.lodz.pl

\section{PHYTOCHEMICALS - IMPORTANT INGREDIENTS OF DIET SUPPLEMENTS AND THEIR IMPACT ON HUMAN} HEALTH

\section{Sum mary}

Phytochemicals are chemical substances produced by plants, exhibiting biological activity and having healthpromoting properties that are valuable to humans. Due to the wide application, good availability and low price, they are important components of dietary supplements, administered in a properly selected dose, in various forms. Thanks to their therapeutic values, they are the target of numerous studies and may be of importance as potential drugs to fight diseases of various origins.

Key words: garlic, ginger, health of human, lycopene, onion, phytocompounds, supplements, tomato 